\title{
Synthesis and Antibacterial Activity of Aromatic Homopropargyl Alcohols
}

\author{
Christian A. Umaña1, María L. Arias², Jorge A. Cabezas ${ }^{1 *}$ \\ ${ }^{1}$ School of Chemistry, University of Costa Rica, San José, Costa Rica \\ ${ }^{2}$ Faculty of Microbiology, University of Costa Rica, San José, Costa Rica \\ Email: *jorge.cabezas@ucr.ac.cr
}

How to cite this paper: Umaña, C.A., Arias, M.L. and Cabezas, J.A. (2017) Synthesis and Antibacterial Activity of Aromatic Homopropargyl Alcohols. International Journal of Organic Chemistry, 7, 295-300.

https://doi.org/10.4236/ijoc.2017.73023

Received: August 26, 2017

Accepted: September 16, 2017

Published: September 19, 2017

Copyright $\odot 2017$ by authors and Scientific Research Publishing Inc. This work is licensed under the Creative Commons Attribution International License (CC BY 4.0).

http://creativecommons.org/licenses/by/4.0/

\begin{abstract}
Several aromatic homopropargyl alcohols, and derivatives were prepared by one-pot reaction of 1,3-dilithiopropyne (or its equivalent) with aldehydes and ketones. The antibacterial activity, of alcohols thus prepared, against Gram (+) and Gram (-) bacteria was tested. This activity varies depending upon substitution on the homopropargyl alcohol unit. Apparently, the benzene ring and the free hydroxyl group (or its alcoxide) are needed, in the homopropargyl alcohol unit, to be biologically active.
\end{abstract}

\section{Keywords}

Homopropargyl Alcohols, 1,3-Dilithiopropyne, Antibacterial Activity

\section{Introduction}

Homopropargyl alcohols are very useful synthetic intermediates in organic synthesis [1] [2]. Numerous methods for their preparation have been developed, using a wide variety of organometallic reagents. Most of them involve reaction of monoanionic propargyl, 1, or allenyl, 2, organometallic reagents, with a carbonyl compound. However, this methodology generally produces mixtures of both, homopropargyl, 3, and allenic, 4, alcohols, which are difficult to separate (Scheme 1). In most of these protocols, the regiochemistry of the product is highly dependent upon factors such as steric hindrance, substitution of the reagent or substrate, solvation and nature of the metal.

We have reported a highly regioselective method for the obtention of aromatic homopropargyl alcohols, 3, from reaction of the operational equivalent of 1,3-dilithipropyne, 5 (obtained from treatment of allene, $\mathbf{6}$, with $n$-BuLi), with aromatic aldehydes or ketones (Scheme 2) [3]. We later envisioned a more 


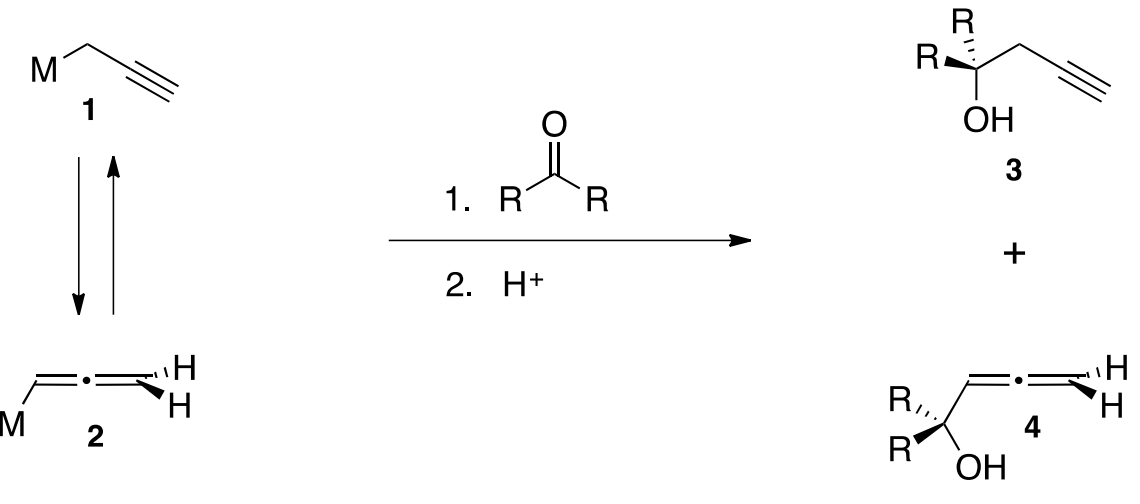

Scheme 1. Formation of alcohols 3 and 4 from organometallics 1 and 2 .
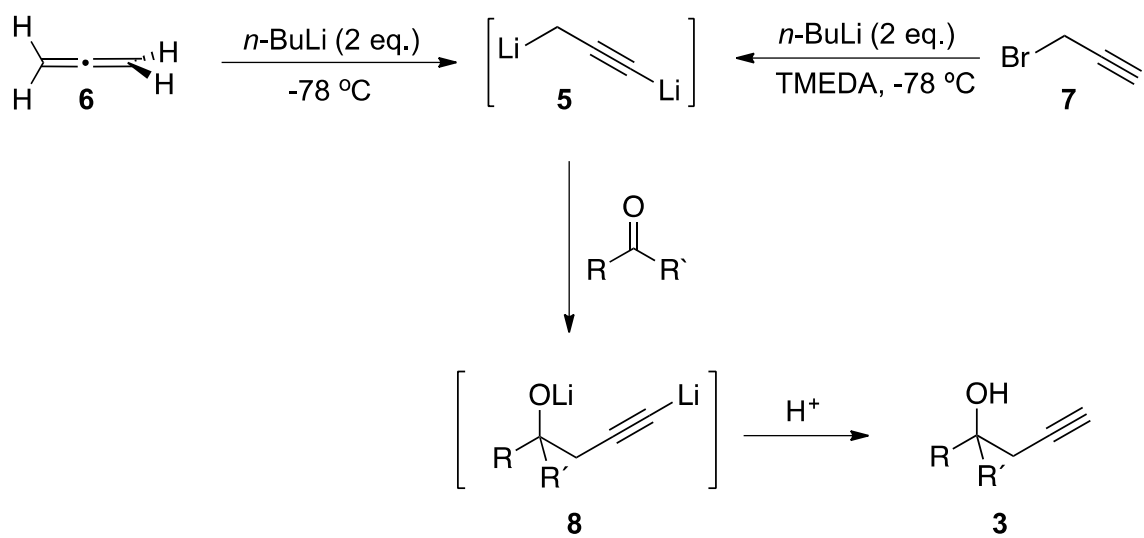

Scheme 2. Preparation of dianion 5.

economical procedure for the preparation of $\mathbf{5}$, from the reaction of propargyl bromide, 7, with $n$-BuLi in the presence of TMEDA (Scheme 2) [4].

We recently reported [5] a new procedure to prepare dianion, 5 , by sequential treatment of 2,3-dichloropropene, 9 , with magnesium and $n$-BuLi in absence of TMEDA (Scheme 3). The latter protocol enabled us to use the lithium acetylide intermediate, $\mathbf{8}$, formed by reaction of dianion $\mathbf{5}$ with aromatic aldehydes and ketones, to perform palladium-catalyzed cross-coupling reactions in one-pot reaction to obtain substituted homopropargyl alcohols type 10 (Scheme 3).

In spite of the fact that homopropargyl alcohols have broad application in organic synthesis, no studies have been reported about its antibacterial activity. The appearance and increase of drug resistance among pathogenic bacteria represents a threat for human health [6]. Bacterial infections due to different bacteria including Staphylococcus aureus, Pseudomonas aeruginosa, Salmonella typhi and Escherichia coli have continued to be a major source of morbidity and mortality not just in hospitals but also among communities [7].

The aim of this work is to report herein the preparation of several homopropargyl alcohols, using procedures depicted in Scheme 2 [4] and Scheme 3 [5], and the determination of its antibacterial activity against both Gram (+) and Gram (-) bacteria. 


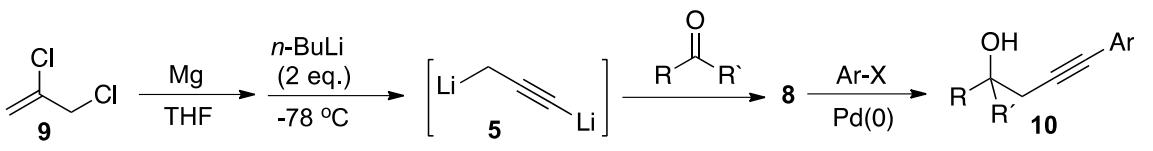

Scheme 3. One-pot synthesis of 4-substituted homopropargyl alcohols 10.

\section{General Methods and Procedures}

\subsection{Materials}

General Information. All glassware and syringes were dried in an oven overnight at $140^{\circ} \mathrm{C}$ and flushed with nitrogen immediately prior to use. Transfers of reagents were performed with syringes equipped with stainless-steel needles. All reactions were carried out under a positive pressure of nitrogen. Nitrogen was passed through a Drierite gas-drying unit prior to use. Diethyl ether and tetrahydrofuran were refluxed and freshly distilled from sodium and potassium/benzophenone ketyl respectively, under nitrogen atmosphere. Hexane was distilled from sodium and collected and kept over activated molecular sieves. $n$-Butyllithium was titrated according to the method of Watson and Eastham [8]. ${ }^{1} \mathrm{H}-\mathrm{NMR}$ and ${ }^{13} \mathrm{C}-\mathrm{NMR}$ spectra were recorded on a $400 \mathrm{MHz}$ Bruker spectrometer. Low resolution mass spectra were obtained on a Agilent Technologies 7820A GC coupled to a mass spectrometer 5977E unit using electron impact at $70 \mathrm{eV}$. High resolution mass were measured on a Waters Synapt HMDS G1, Q-TOF. Infrared spectra were recorded on a Perkin Elmer FT-IR Spectrum 1000.

Homopropargyl alcohols 11, 12, 13 and 18 were prepared from dichloropropene, 9, according to Scheme 3 as in [5]. Derivatives 14 and 15 were prepared from alcohol 12, by reaction with $\mathrm{NaH}$ and acetylation respectively. Compounds 16 and 17 were synthesized from propargyl bromide, 7, according to Scheme 2 as in [4], and adding NBS and dry ice to the intermediate 8, respectively.

2-phenyl-4-pentyn-2-yl acetate. (15) IR (film): $v_{\max } 3292,2119,1754,1495$, $1447,1375,1369,1228,1126 \mathrm{~cm}^{-1} ;{ }^{1} \mathrm{H} \mathrm{RMN}\left(400 \mathrm{MHz}, \mathrm{CDCl}_{3}\right): \delta 7.49(\mathrm{~m}, 2 \mathrm{H}$,$) ,$ $7.36(\mathrm{~m}, 2 \mathrm{H}), 7.30(\mathrm{~m}, 1 \mathrm{H}), 2.78(\mathrm{dd}, J=2.6,16.6 \mathrm{~Hz}, 1 \mathrm{H}), 2.71(\mathrm{~d}, J=2.6,16.6$ $\mathrm{Hz}, 1 \mathrm{H}), 2.19$ (s, 3H), $2.06(\mathrm{t}, J=2.6 \mathrm{~Hz}, 1 \mathrm{H}) 1.65(\mathrm{~s}, 3 \mathrm{H})$; MS (EI) m/z (relative intensity) 39.1 (10), 43.1 (51), 77.1 (18), 105.1 (15), 121.1 (100), 142.1 (15), 163.1 (20), $202.2(1)$.

5-bromo-2-phenyl-4-pentyn-2-ol. (16) IR (film): $v_{\max } 3411,2119,1495$, 1446, 1375, $1101 \mathrm{~cm}^{-1}$; ${ }^{1} \mathrm{H}$ RMN (400 MHz, $\left.\mathrm{CDCl}_{3}\right): \delta 7.49(\mathrm{~m}, 2 \mathrm{H}), 7.36(\mathrm{~m}$, 2H), $7.30(\mathrm{~m}, 1 \mathrm{H}), 2.78(\mathrm{~d}, J=16.6 \mathrm{~Hz}, 1 \mathrm{H}), 2.71(\mathrm{~d}, J=16.6 \mathrm{~Hz}, 1 \mathrm{H}), 1.65(\mathrm{~s}$, $3 \mathrm{H}$ ); MS (EI) m/z (relative intensity) 43.1 (83), 77.1 (20), 105.1 (13), 116 (2), 121.1 (100), 222.1 (1).

5-hydroxy-5-phenyl-2-hexynoic acid. (17) IR (film): $v_{\max } 3400$ - 2600, 2239, 1692, 1495, 1446, 1377, $1070 \mathrm{~cm}^{-1} ;{ }^{1} \mathrm{H} \mathrm{RMN}\left(400 \mathrm{MHz}, \mathrm{CDCl}_{3}\right): \delta 12.25(\mathrm{~s}, 1 \mathrm{H})$, $7.49(\mathrm{~m}, 2 \mathrm{H}), 7.36(\mathrm{~m}, 2 \mathrm{H}), 7.30(\mathrm{~m}, 1 \mathrm{H}), 2.92(\mathrm{~d}, J=17.4 \mathrm{~Hz}, 1 \mathrm{H}), 2.85(\mathrm{~d}, J=$ $17.4 \mathrm{~Hz}, 1 \mathrm{H}), 1.65$ (s, 3H).

(Z)-7-chloro-2-phenyl-6-en-4-heptyn-2-ol (18). (0.104 g, 62\%); IR (KBr): $v_{\max } 3401,2214,1601,1494,1446,1098 \mathrm{~cm}^{-1} ;{ }^{1} \mathrm{H} \mathrm{NMR}\left(400 \mathrm{MHz}, \mathrm{CDCl}_{3}\right): \delta 7.51$ 
(m, 2H), $7.36(\mathrm{~m}, 2 \mathrm{H}), 7.27(\mathrm{~m}, 1 \mathrm{H}), 6.34(\mathrm{~d}, 1 \mathrm{H}, J=7.4 \mathrm{~Hz}), 5.83(\mathrm{dt}, 1 \mathrm{H}, J=$ 2.2, 7.4 Hz), $2.95(\mathrm{dd}, 1 \mathrm{H}, J=2.2,16.9 \mathrm{~Hz}), 2.89(\mathrm{dd}, 1 \mathrm{H}, J=2.2,16.9 \mathrm{~Hz}), 2.50$ (s, $1 \mathrm{H}), 1.69$ (s, 3H); ${ }^{13} \mathrm{C}$ NMR (100 MHz, $\left.\mathrm{CDCl}_{3}\right): \delta 146.5,128.4,128.3,127.2$, 124.9, 112.1, 94.8, 78.1, 73.6, 36.1, 29.4; MS (EI) m/z (rel. intensity) 43.1 (76), 77.1 (15), 99.0 (4), 105.1 (8), 121.1 (100), $183.2\left(\mathrm{M}^{+}\right.$- HCl, 10) HRMS (ESI, $\left.\mathrm{V}^{+}\right)$: $\mathrm{m} / z\left[\mathrm{M}^{+}-\mathrm{HCl}\right]^{+}$calc. for $\mathrm{C}_{13} \mathrm{H}_{13} \mathrm{O} 185.0966$, found 185.0968 .

\subsection{Antibacterial Activity}

Microorganisms tested. Cultures of Leuconostoc mesenteroides (ATCC 8293-2), Lactobacillus plantarum (ATCC 14917), Staphylococcus aureus (ATCC 25922), Listeria monocytogenes (ATCC 19116) Escherichia coli (ATCC 25923) Pseudomonas aeruginosa (ATCC 15442) and Salmonella enteritidis (ATCC 13076) were used.

Suspension preparation. Each microorganism was inoculated into trypticase soy broth $(\mathrm{TSB})+$ yeast $\left(\mathrm{Oxoid}^{\star}\right)$ and cultured at $37 \times$ until the desired concentration was reached. The suspension of bacteria to be cultured was equivalent to $0.5 \mathrm{McF}$ arland standard, $\left(1.5 \times 10^{8} \mathrm{CFU} / \mathrm{ml}\right)$.

Bactericidal assays. All tests were performed by duplicate. The microorganism to be tested was uniformly spread with sterile cotton swab over MRS agar for $L$. plantarum and $L$ mesenteroides and overtrypticase soy agar plate for the other bacteria. All agar plates were prepared using $20 \mathrm{ml}$ of agar and allowed to solidify uniformly. $7 \mathrm{~mm}$ diameter holes were cut in the agar gel, $20 \mathrm{~mm}$ apart from each one.100 $\mathrm{ul}$ of inoculum suspension was swabbed uniformly in the corresponding agar plates.

Five serial dilutions of synthetic products, at concentrations of 100, 50, 25, 12.5 and $6 \mathrm{mg} / \mathrm{mL}$ were prepared. $50 \mu \mathrm{L}$ of each dilution were added to holes. Test systems were incubated for $24 \mathrm{~h}$ at $35^{\circ} \mathrm{C}$ under aerobic conditions except for $L$. plantarum and $L$. mesenteroides that were cultured under capnophilic conditions. The MIC was defined as the lowest concentration of the sample that prevented visible growth.

\section{Results and Discussion}

In order to compare their biological activity, we decided to prepare a series of homopropargyl alcohols unsubstituted in the acetylenic position $(11,12,13)$, some salts and acetylated derivatives (14 and 15) and some 4-substituted acetylenic alcohols $(16,17,18)$.

The minimal inhibitory concentration (MIC) of the different homopropargyl alcohols prepared is shown in Table 1. All structures presented some inhibitory activity against the microorganisms tested, nevertheless, products 14 and 17 presented activity against all of them, including Pseudomonas sp, one of the most resistant microorganisms described. Both have MICs that range from 25 to $50 \mathrm{mg} / \mathrm{mL}$. Compounds 14 and 17 are derived from alcohol 12. Activity of sodium salt 14 was enhanced when compared with parent compound 12, perhaps because a greater solubility. When compound 12 was brominated in the acety- 
Table 1. Antibacterial Activity of some Aromatic Homopropargyl Alcohols against Gram $(+)$ and Gram (-) Bacteria.

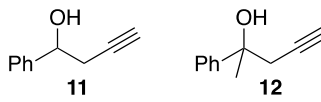<smiles>C#CCC(O)(c1ccccc1)c1ccccc1</smiles><smiles>C#CCC(C)(O[Na])c1ccccc1</smiles><smiles>C#CCC(C)(CC#C)c1ccccc1</smiles><smiles>CC(O)(C#CBr)c1ccccc1</smiles><smiles>O=C(O)C#CC(O)(F)c1ccccc1</smiles>

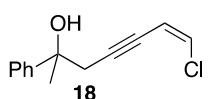

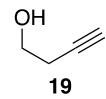

Compound Minimum Inhibitory Concentration $(\mathrm{MIC})^{\star}(\mathrm{mg} / \mathrm{mL})$

\begin{tabular}{ccccccccccc}
\hline Entry & Microorganism & 11 & $\mathbf{1 2}$ & $\mathbf{1 3}$ & $\mathbf{1 4}$ & $\mathbf{1 5}$ & $\mathbf{1 6}$ & $\mathbf{1 7}$ & $\mathbf{1 8}$ & $\mathbf{1 9}$ \\
\hline 1 & Lactobacillus plantarum & 50 & $(-)$ & 100 & 25 & $(-)$ & 12 & 25 & 20 & $(-)$ \\
2 & Listeria monocytogenes & 25 & 50 & 100 & 25 & $(-)$ & 25 & 50 & 20 & $(-)$ \\
3 & Leuconostoc mesenteroides & $(-)$ & 50 & 25 & 25 & $(-)$ & 50 & 25 & 20 & $(-)$ \\
4 & Staphylococcus aureus & 25 & 25 & 50 & 50 & $(-)$ & 12 & 50 & 20 & $(-)$ \\
5 & Escherichia coli & 50 & 50 & 50 & 25 & $(-)$ & 25 & 50 & $(-)$ & $(-)$ \\
6 & Salmonella spp & $(-)$ & 50 & $(-)$ & 25 & $(-)$ & 25 & 50 & $(-)$ & $(-)$ \\
7 & Pseudomonas spp & $(-)$ & 100 & 100 & 50 & $(-)$ & $(-)$ & 50 & 20 & $(-)$ \\
\hline
\end{tabular}

${ }^{\star} \mathrm{MIC}$ was defined as the lowest concentration of the sample that prevented visible growth. For MIC determination, control strains included Escherichia coli ATCC 25922, Pseudomonas aeruginosa ATCC 27853 and Staphylococcus aureus ATCC 49619.

lenic position to obtain derivative 16, the biological activity was enhanced, except in the case of Pseudomonas spp. In the case of Staphylococcus aureus activity of derivative 16 was twice as active as 12 . Interestingly, when the hydroxyl group of alcohol 12, was acetylated (15), the activity against all the microorganisms was lost. In chloroenyne18, activity against Gram (+) bacteria was enhanced when compared to parent compound 12 .

When activity of 3-butyn-1-ol, 19, was tested, it was negative against all microorganisms, showing that the presence of the aromatic ring in the homopropargyl alcohol unit is needed in order to have some biological activity.

\section{Conclusions}

In summary, several aromatic homopropargyl alcohols were prepared, by one-pot reaction of dianion, 5 , with aromatic aldehydes and ketones. The antibacterial activity of the compounds thus prepared, against Gram (+) and Gram $(-)$ bacteria was tested. This antibacterial activity varies depending upon substitution on the homopropargyl alcohol unit. Apparently, the benzene ring and the free hydroxyl group (or its alcoxide) are needed in the homopropargyl alcohol unit to be biologically active, as it may be concluded by comparison of activity of compounds $11,12,13,14,15$ and 19. It is not clear what induces the difference in antibacterial activity between compounds $11,12,13$ because there is no clear trend in activity between them, neither for Gram (+) nor for Gram (-) microorganisms.

The development of novel, non-toxic-food compatible chemical products could help to reduce the presence of pathogens and spoilage microorganisms from food industry environments, including surfaces, equipment and even worker hands. Further research has to be done to test toxicity of compounds in Table 1. 


\section{Acknowledgements}

We thank Sistema de Estudios de Posgrado (SEP-UCR) for a stipend to C.U., CIPRONA-UCR for high resolution mass spectra determination, the Bacteriology Laboratory of Microbiology Faculty, University of Costa Rica for kindly supplying the bacteria and Vicerrectoría de Investigación (UCR) for financial support.

\section{References}

[1] Urabe, F., Miyamoto, S., Takahashi, K., Ishihara, J. and Hatakeyama, S. (2014) Formal [4 + 1]-Cycloaddition of Homopropargyl Alcoholsto Diazo Dicarbonyl Compounds Giving Substituted Tetrahydrofurans. Organic Letters, 16, 1004-1007. https://doi.org/10.1021/ol403746r

[2] Hosseyni, S., Wojtas, L., Li, M. and Shi, X. (2016) Intermolecular Homopropargyl Alcohol Additionto Alkyne and a Sequential 1,6-Enyne Cycloisomerization with Triazole-Gold Catalyst. Journal of the American Chemical Society, 138, 3994-3997. https://doi.org/10.1021/jacs.6b00882

[3] Cabezas, J.A. and Alvarez, L.X. (1998) Propargylation of Carbonylcompounds: An Efficient Method for the Synthesis of Homopropargyl Alcohols. Tetrahedron Letters, 39, 3935-3938. https://doi.org/10.1016/S0040-4039(98)00727-8

[4] Cabezas, J.A., Pereira, A.R. and Amey, A. (2001) A New Method for the Preparation of 1,3-Dilithiopropyne: An Efficient Synthesis of Homopropargyl Alcohols. Tetrahedron Letters, 42, 6819-6822. https://doi.org/10.1016/S0040-4039(01)01429-0

[5] Umaña, C. and Cabezas, J.A. (2017) Palladium-Catalyzed One-Pot Conversion of Aldehydes and Ketones into 4-Substituted Homopropargyl Alcohols and 5-En-3-yn-1-ols. Journal of Organic Chemistry. https://doi.org/10.1021/acs.joc.7b01529

[6] Sidjui, L.S., Toghueo, R.M.K., Zeukó, E.M., Mbouna, C.D.J., Mahiou-Leddet, V., Herbette, G., Beyom, F., Ollivier, E. and Ngosong, G. (2016) Antibacterial Activity of the Crude Extracts, Fractions and Compounds from the Stem Barks of Jacaranda mimosifolia and Kigelia Africana (Bignoniaceae). Pharmacologia, 7, 22-31. https://doi.org/10.5567/pharmacologia.2016.22.31

[7] Valgas, C., Machado de Souza, C.S., Smania, E. and Smania, A. (2007) Screening Methods to Determine Antibacterial Activity of Natural Products. Brazilian Journal of Microbiology, 38, 369-380. https://doi.org/10.1590/S1517-83822007000200034

[8] Watson, S.C. and Eastham, J.F. (1967) Colored Indicators for Simple Directtitration of Magnesium and Lithiumreagents. Journal of Organometallic Chemistry, 9, 165-168. https://doi.org/10.1016/S0022-328X(00)92418-5 
Submit or recommend next manuscript to SCIRP and we will provide best service for you:

Accepting pre-submission inquiries through Email, Facebook, LinkedIn, Twitter, etc. A wide selection of journals (inclusive of 9 subjects, more than 200 journals)

Providing 24-hour high-quality service

User-friendly online submission system

Fair and swift peer-review system

Efficient typesetting and proofreading procedure

Display of the result of downloads and visits, as well as the number of cited articles Maximum dissemination of your research work

Submit your manuscript at: http://papersubmission.scirp.org/

Or contact ijoc@scirp.org 